\title{
Direct Synthesis of Hydrogen Peroxide from Hydrogen and Oxygen by Using a Water-Soluble Iridium Complex and Flavin Mononucleotide**
}

\author{
Satoshi Shibata, Tomoyoshi Suenobu, and Shunichi Fukuzumi*
}

Hydrogen peroxide $\left(\mathrm{H}_{2} \mathrm{O}_{2}\right)$ is known to be a highly selective and environmentally friendly oxidant and is used in the chemical industry for the manufacture of numerous organic and inorganic compounds. ${ }^{[1,2]}$ However, the current industrial process for $\mathrm{H}_{2} \mathrm{O}_{2}$ production by sequential hydrogenation and oxidation of an alkyl anthraquinone is not environmentally benign as a result of a number of disadvantages, such as the requirement for toxic solvents, high energy consumption, and multiple steps. ${ }^{[3,4]}$ To provide an alternative, extensive efforts have been devoted to achieving the direct synthesis of $\mathrm{H}_{2} \mathrm{O}_{2}$ from hydrogen $\left(\mathrm{H}_{2}\right)$ and oxygen $\left(\mathrm{O}_{2}\right)$ by using heterogeneous precious-metal catalysts (mainly $\mathrm{Pd}, \mathrm{Au}$, or $\mathrm{Au}-\mathrm{Pd}$ ).$^{\left[{ }^{-12]}\right.}$ This direct process suffers from serious problems such as unfavorable high-pressure conditions and relatively low yields owing to undesired side reactions such as formation of $\mathrm{H}_{2} \mathrm{O}$ $\left(\mathrm{H}_{2}+{ }^{1} / 2 \mathrm{O}_{2} \rightarrow \mathrm{H}_{2} \mathrm{O}\right)$, decomposition of $\mathrm{H}_{2} \mathrm{O}_{2}\left(\mathrm{H}_{2} \mathrm{O}_{2} \rightarrow \mathrm{H}_{2} \mathrm{O}+\right.$ $\left.1 / 2 \mathrm{O}_{2}\right)$, and hydrogenation of $\mathrm{H}_{2} \mathrm{O}_{2}\left(\mathrm{H}_{2} \mathrm{O}_{2}+\mathrm{H}_{2} \rightarrow 2 \mathrm{H}_{2} \mathrm{O}\right){ }^{[3-12]}$ For this reason, selectivity in the direct synthesis of $\mathrm{H}_{2} \mathrm{O}_{2}$ from $\mathrm{H}_{2}$ and $\mathrm{O}_{2}$ has been limited. In addition, it has been quite difficult to elucidate the heterogeneous catalytic mechanism as compared with the homogeneous catalytic mechanism, in which intermediates can be detected. However, there has to date been no report of a homogeneous catalytic system for the direct synthesis of $\mathrm{H}_{2} \mathrm{O}_{2}$ from $\mathrm{H}_{2}$ and $\mathrm{O}_{2} \cdot{ }^{[13]}$

We report herein the direct synthesis of $\mathrm{H}_{2} \mathrm{O}_{2}$ from $\mathrm{H}_{2}$ and $\mathrm{O}_{2}$ in water by using a water-soluble iridium aqua complex

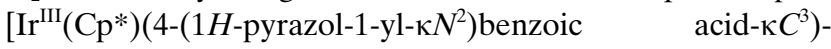
$\left.\left(\mathrm{H}_{2} \mathrm{O}\right)\right]_{2} \mathrm{SO}_{4}\left([\mathbf{1}]_{2} \mathrm{SO}_{4}\right)$, which can react with $\mathrm{H}_{2}$ to produce an iridium hydride complex (2), ${ }^{[14,15]}$ and flavin mononucle-

[*] S. Shibata, Dr. T. Suenobu, Prof. Dr. S. Fukuzumi Department of Material and Life Science Graduate School of Engineering, Osaka University

2-1 Yamada-oka, Suita, Osaka 565-0871 (Japan)

E-mail: fukuzumi@chem.eng.osaka-u.ac.jp

Homepage: http://www-etchem.mls.eng.osaka-u.ac.jp/

Prof. Dr. S. Fukuzumi

Department of Bioinspired Science, Ewha Womans University Seoul 120-750 (Korea)

[**; This work was supported by Grants-in-Aid (Nos. 20108010 and 24550077) from the Ministry of Education, Culture, Sports, Science and Technology (Japan) and NRF/MEST of Korea through the WCU (R31-2008-000-10010-0) and GRL (2010-00353) Programs.

Supporting information for this article is available on the WWW under http://dx.doi.org/10.1002/anie.201307273.

of (c) 2013 The Authors. Published by Wiley-VCH Verlag GmbH \& Co. $\mathrm{KGaA}$. This is an open access article under the terms of the Creative Commons Attribution Non-Commercial NoDerivs License, which permits use and distribution in any medium, provided the original work is properly cited, the use is non-commercial and no modifications or adaptations are made. otide (FMN) under normal pressure and at room temperature. The synthesis and characterization of 1 were carried out as reported and are briefly described in the Experimental Section. ${ }^{[14]}$

At $\mathrm{pH}$ 6.0, the carboxylic acid group in $\mathbf{1}$ is deprotonated to give the carboxylate form 1-H ${ }^{+}$[Eq. (1)]. ${ }^{[14]}$ The $\mathrm{Ir}^{\mathrm{III}}-\mathrm{OH}_{2}$ complex $\mathbf{1 - \mathbf { H } ^ { + }}$ reacts with $\mathrm{H}_{2}$ in an aqueous phosphate buffer solution ( $\mathrm{pH}$ 6.0) to produce the iridium(III) hydride complex $2\left(\lambda_{\max }=336 \mathrm{~nm}\right.$; Equation (2) and Figure 1) ${ }^{[14]}$ The reaction

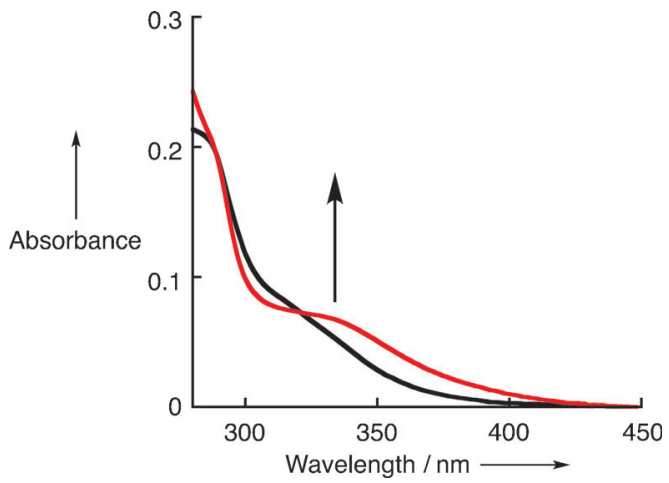

Figure 1. Changes in the UV/Vis absorption spectrum during the reaction of $1(25 \mu \mathrm{M})$ with $\mathrm{H}_{2}(0.82 \mathrm{~mm})$ in an aqueous phosphate buffer ( $\mathrm{pH}$ 6.0) at $298 \mathrm{~K}$. An argon-saturated buffer solution of 1 (black line) was bubbled with $\mathrm{H}_{2}\left(1.0 \times 10^{-1} \mathrm{MPa}\right)$ for 5 min thus resulting in the formation of 2 (red line).

of $\mathbf{1 - \mathbf { H } ^ { + }}$ with $\mathrm{H}_{2}$ proceeds rapidly to completion to form $\mathbf{2}$ within $3 \mathrm{~s}$ (Figure $\mathrm{S} 1$ in the Supporting Information). For the reaction of $\mathbf{1 - \mathbf { H } ^ { + }}$ with $\mathrm{H}_{2}$, the formation of $\mathbf{2}$ in the presence of $\mathrm{O}_{2}$ was confirmed by changes in the UV/Vis absorption spectrum, which indicates the slower reaction of 2 with $\mathrm{O}_{2}$ (Figure S2 in the Supporting Information).
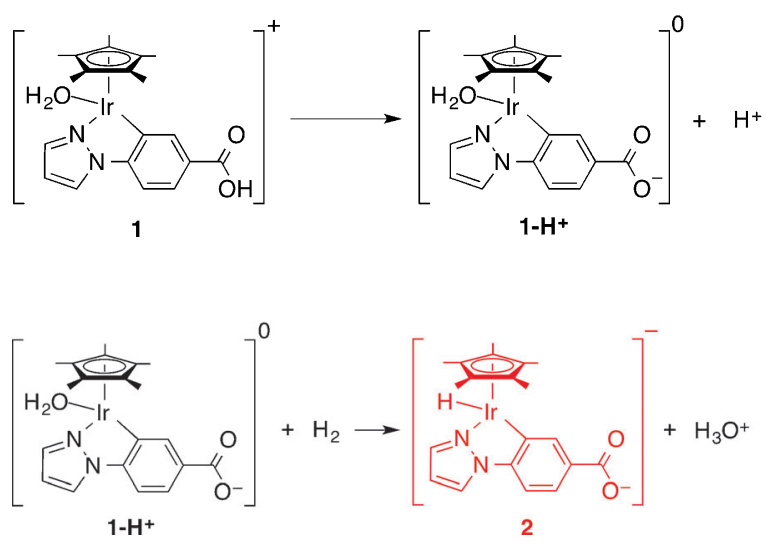
Complex 2 can efficiently reduce FMN $\left(\lambda_{\max }=373\right.$ and $445 \mathrm{~nm})$ to the 1,5 -dihydroflavin $\left(\mathrm{FMNH}_{2}: \lambda_{\max }=291 \mathrm{~nm}\right.$ and $390 \mathrm{~nm}$ ) in aqueous phosphate buffer solution ( $\mathrm{pH}$ 6.0) under $\mathrm{N}_{2}$ [Equation (3) and Figure 2]. ${ }^{[16]} \mathrm{FMNH}_{2}$ was also generated
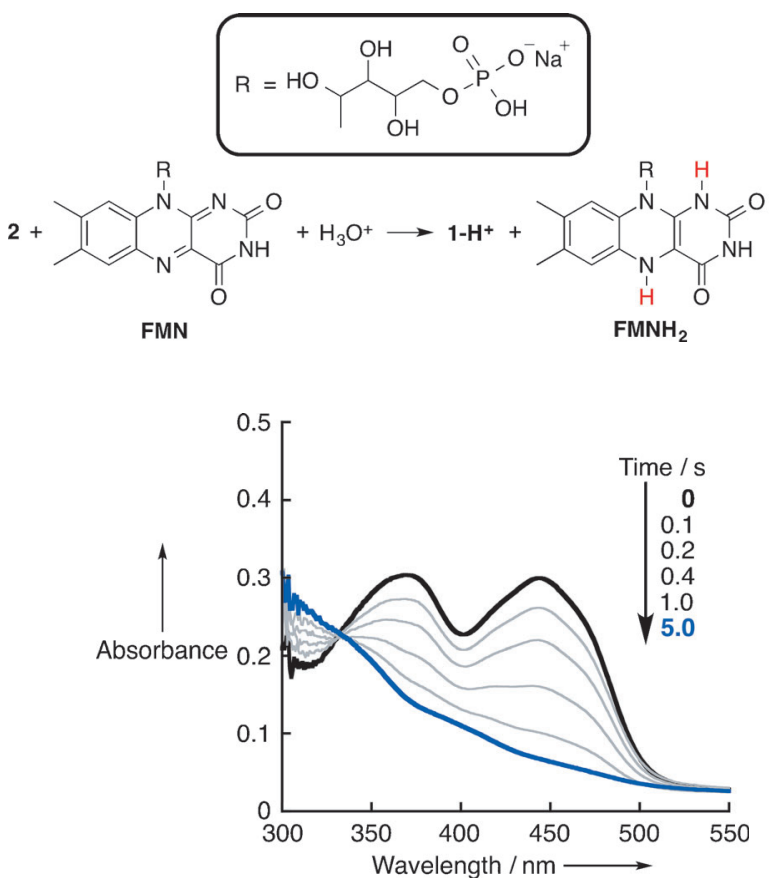

Figure 2. Changes in the UV/Vis absorption spectrum during the reduction of FMN $(25 \mu \mathrm{M})$ by $2(0.55 \mathrm{mM})$ under an $\mathrm{H}_{2}$ $\left(5.0 \times 10^{-2} \mathrm{MPa}\right) / \mathrm{N}_{2}\left(5.0 \times 10^{-2} \mathrm{MPa}\right)$ gas mixture after mixing a buffer solution of FMN $(50 \mu \mathrm{M})$ under $\mathrm{N}_{2}$ with that of $\mathbf{2}$. Complex $\mathbf{2}$ was formed by the reduction of $1\left(1.1 \mathrm{mM}\right.$ ) by $\mathrm{H}_{2}$ (bubbling for $10 \mathrm{~min}$ ) under normal pressure in an aqueous phosphate buffer $(\mathrm{pH} \mathrm{6.0)}$ at $298 \mathrm{~K}$. The black and blue solid lines correspond to FMN and $\mathrm{FMNH}_{2}$, respectively.

by catalytic reduction of FMN with $\mathrm{H}_{2}$ in the presence of 1 (Figure S3 in the Supporting Information). A similar spectral change has been reported in the reaction of FMN with sodium dithionite in water ${ }^{[15]}$ The wavelengths $\left(\lambda_{\max }\right)$ and extinction coefficients at $\lambda_{\max }$ for the absorption spectrum of $\mathrm{FMNH}_{2}$ obtained in this work $\left(\varepsilon=3.6 \times 10^{3} \mathrm{M}^{-1} \mathrm{~cm}^{-1}\right.$ at $\lambda_{\max }=$ $390 \mathrm{~nm}$ ) are consistent with those in the literature ${ }^{[14]}$ thus indicating the stoichiometric formation of $\mathrm{FMNH}_{2}$. The decay of the absorption band of FMN at $\lambda_{\max }=445 \mathrm{~nm}$ obeyed second-order kinetics (Figure S4a in the Supporting Information). Irrespective of the ratio of the initial amounts of $\mathbf{2}$ to FMN, the observed second-order rate constants $\left(k_{\mathrm{B}}\right)$ agree well with each other $\left(1.5 \times 10^{5} \mathrm{M}^{-1} \mathrm{~s}^{-1}\right.$ and $1.2 \times 10^{5} \mathrm{M}^{-1} \mathrm{~s}^{-1}$, Figure S4 $\mathrm{a}$ and $\mathrm{b}$ in the Supporting Information, respectively).

$\mathrm{FMNH}_{2}$ can readily be oxidized by $\mathrm{O}_{2}$ to regenerate FMN, accompanied by the formation of $\mathrm{H}_{2} \mathrm{O}_{2}$ [Eq. (4)]. ${ }^{[17]}$ Upon

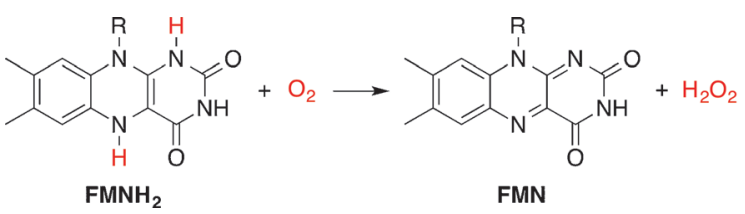

mixing an $\mathrm{O}_{2}$-saturated phosphate buffer solution with a buffer solution of $\mathrm{FMNH}_{2}$ that was formed by the reduction of $\mathrm{FMN}$ by $\mathrm{H}_{2}$ in the presence of $\mathbf{1}$, the characteristic absorption bands of FMN were completely regenerated (Figure 3 ). The rise of the absorption band of FMN at

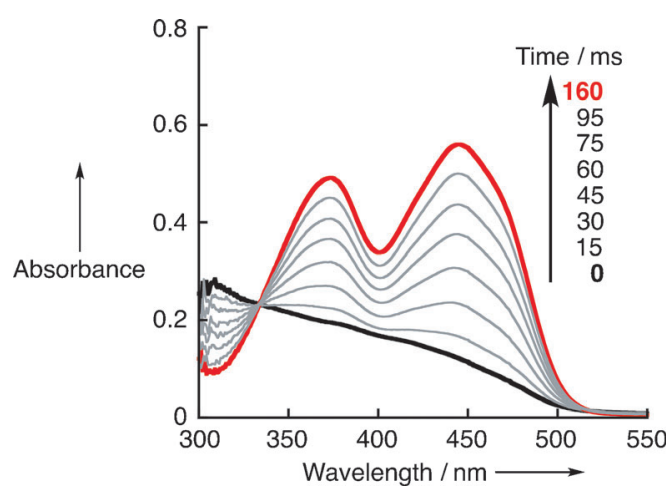

Figure 3. Changes in the UV/Vis absorption spectrum during the oxidation of $\mathrm{FMNH}_{2}(50 \mu \mathrm{M})$ by $\mathrm{O}_{2}(0.68 \mathrm{~mm})$ under an $\mathrm{O}_{2}$ $\left(5.0 \times 10^{-2} \mathrm{MPa}\right) / \mathrm{N}_{2}\left(5.0 \times 10^{-2} \mathrm{MPa}\right)$ gas mixture in an aqueous phosphate buffer $\left(\mathrm{pH}\right.$ 6.0) after mixing an $\mathrm{O}_{2}$-saturated buffer solution with a buffer solution of $\mathrm{FMNH}_{2}$ under $\mathrm{N}_{2}$. $\mathrm{FMNH}_{2}$ was formed in the reduction of FMN (100 $\mu \mathrm{M})$ by $\mathrm{H}_{2}$ (bubbling for $10 \mathrm{~min}$ ) with $1(5.0 \mu \mathrm{M})$ under normal pressure at $298 \mathrm{~K}$.

$\lambda_{\max }=445 \mathrm{~nm}$ obeyed first-order kinetics (Figure S5 in the Supporting Information). From the slope of the first-order plot (inset of Figure S5 in the Supporting Information), a pseudo-first-order rate constant $\left(k_{\text {obs }}\right)$ was obtained, and the second-order rate constant $\left(k_{\mathrm{C}}\right)$ for the reaction of $\mathrm{FMNH}_{2}$ with $\mathrm{O}_{2}$ was determined to be $2.0 \times 10^{4} \mathrm{M}^{-1} \mathrm{~s}^{-1}$.

$\mathrm{FMNH}_{2}$ can also be independently generated by the reduction of FMN with sodium hydrosulfite $\left(\mathrm{Na}_{2} \mathrm{~S}_{2} \mathrm{O}_{4}\right) \cdot{ }^{[16 a]}$ As the reaction of $\mathrm{FMNH}_{2}$ with $\mathrm{O}_{2}$ proceeds, the formation of FMN leads to an increase in the absorbance at $\lambda_{\max }=445 \mathrm{~nm}$, and this increase obeyed first-order kinetics (Figure S6a in the Supporting Information). The pseudo-first-order rate constant $\left(k_{\text {obs }}\right)$ proportionally increased with concentration of $\mathrm{O}_{2}$ (Figure $\mathrm{S} 6 \mathrm{~b}$ in the Supporting Information). From the slope of the linear plot, the second-order rate constant for the reaction of $\mathrm{FMNH}_{2}$ with $\mathrm{O}_{2}$ was determined to be $2.8 \times$ $10^{4} \mathrm{M}^{-1} \mathrm{~s}^{-1}$. This value agrees well with $k_{\mathrm{C}}$ determined for the reaction in the presence of $\mathbf{1}$ and $\mathrm{H}_{2}$. These values are more or less consistent with the value $\left(5.8 \times 10^{4} \mathrm{M}^{-1} \mathrm{~s}^{-1}\right)$ reported for the reaction of a reduced form of a flavoprotein oxidase with $\mathrm{O}_{2}$ at $\mathrm{pH}$ 7.0..$^{[18]}$

The amount of $\mathrm{H}_{2} \mathrm{O}_{2}$ produced was determined by titration with the oxo[5,10,15,20-tetra(4-pyridyl)porphyrinato]titanium(IV) complex. ${ }^{[19]}$ In the reaction consisting of the stepwise reduction of $\mathrm{FMN}$ by $\mathrm{H}_{2}$ to form $\mathrm{FMNH}_{2}$ when using 1 followed by the oxidation of $\mathrm{FMNH}_{2}$ by $\mathrm{O}_{2}$ to generate $\mathrm{H}_{2} \mathrm{O}_{2}$, a stoichiometric amount of $\mathrm{H}_{2} \mathrm{O}_{2}$ was produced when the concentration of FMN was varied, thus demonstrating a linear relationship between the concentrations of $\mathrm{H}_{2} \mathrm{O}_{2}$ and FMN with a slope of 1.0 (Figure 4).

Thus, the overall catalytic cycle for the selective direct synthesis of $\mathrm{H}_{2} \mathrm{O}_{2}$ from $\mathrm{H}_{2}$ and $\mathrm{O}_{2}$ by using $\mathrm{I}$ and FMN is 


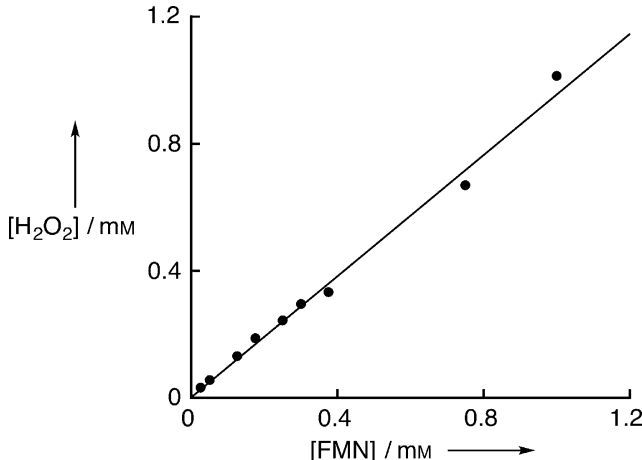

Figure 4. Plot of the concentration of $\mathrm{H}_{2} \mathrm{O}_{2}$ produced by the catalytic reduction of $\mathrm{O}_{2}\left(1.0 \times 10^{-1} \mathrm{MPa}\right)$ by $\mathrm{FMNH}_{2}$ (generated through the reduction of $\mathrm{FMN}$ by 2 under $\mathrm{H}_{2}$ ) versus the concentration of FMN $(25 \mu \mathrm{M}-1.0 \mathrm{mM})$ loaded at the beginning of the reaction at $298 \mathrm{~K} .2$ was produced by the reduction of $1(25 \mu \mathrm{M})$ by $\mathrm{H}_{2}\left(1.0 \times 10^{-1} \mathrm{MPa}\right)$ in an aqueous phosphate buffer solution $(\mathrm{pH} 6.0)$.

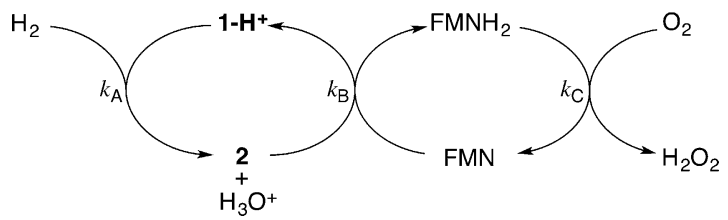

Scheme 1.

expected to proceed according to Scheme 1: the iridium(III) complex 1-H $\mathbf{H}^{+}$reacts with $\mathrm{H}_{2}$ to produce the $\mathrm{Ir}^{\mathrm{III}}-\mathrm{H}$ complex $\mathbf{2}$, which reduces $\mathrm{FMN}$ to $\mathrm{FMNH}_{2}$, followed by oxidation by $\mathrm{O}_{2}$ to produce $\mathrm{H}_{2} \mathrm{O}_{2}$, accompanied by the regeneration of FMN.

When the catalytic reduction of FMN $(5.0 \mu \mathrm{M})$ followed by the oxidation of $\mathrm{FMNH}_{2}$ by $\mathrm{O}_{2}$ was made possible by the presence of $\mathbf{1}(5.0 \mu \mathrm{M})$ in an aqueous phosphate buffer solution ( $\mathrm{pH}$ 6.0), $\mathrm{H}_{2} \mathrm{O}_{2}$ was catalytically produced from $\mathrm{H}_{2}$ and $\mathrm{O}_{2}$. The formation of $\mathrm{H}_{2} \mathrm{O}_{2}$ stopped within a few minutes at $\mathrm{pH} 6.0$ and $100 \mathrm{~min}$ at $\mathrm{pH} 2.8$, when the turnover number (TON) of $\mathrm{H}_{2} \mathrm{O}_{2}$ production with respect to $\mathbf{1}$ and FMN reached 28 at $\mathrm{pH} 6.0$ and 41 at $\mathrm{pH} 2.8$ (Figure 5, black $\bullet$ ). This

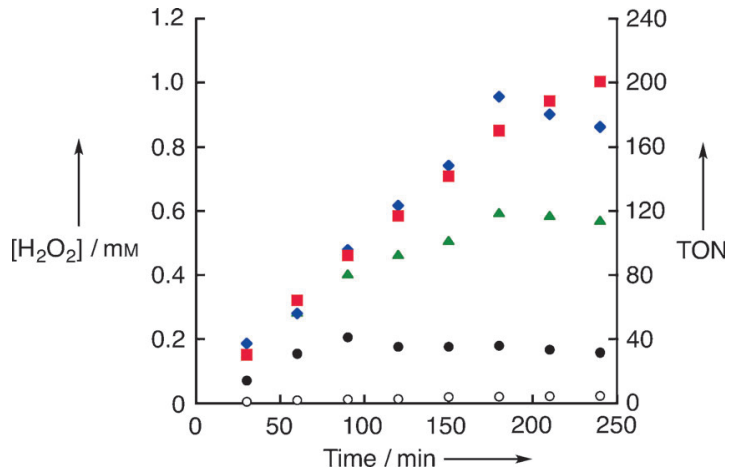

Figure 5. Time course of $\mathrm{H}_{2} \mathrm{O}_{2}$ production by the reaction of $\mathrm{H}_{2}$ $\left(5.0 \times 10^{-2} \mathrm{MPa}\right)$ with $\mathrm{O}_{2}\left(5.0 \times 10^{-2} \mathrm{MPa}\right)$ catalyzed by $1(5.0 \mu \mathrm{M})$ and FMN $(5.0 \mu \mathrm{M})$ in water $(\mathrm{pH} 2.8)$ at $298 \mathrm{~K}$ in the absence (black •) or presence of $\mathrm{Sc}\left(\mathrm{NO}_{3}\right)_{3}(25,50$, and $100 \mathrm{~mm}$; green $\boldsymbol{\Delta}$, blue $\bullet$, and red a, respectively). Data shown by $\bigcirc$ were obtained in the absence of FMN but with $1(5.0 \mu \mathrm{M})$ and $\mathrm{Sc}\left(\mathrm{NO}_{3}\right)_{3}(100 \mathrm{~mm})$ under otherwise the same experimental conditions. limited TON stands in sharp contrast to the stepwise catalytic reduction of FMN and the oxidation of $\mathrm{FMNH}_{2}$ by $\mathrm{O}_{2}$ (see above).

When $\mathrm{Sc}\left(\mathrm{NO}_{3}\right)_{3}(100 \mathrm{~mm})$ was added to this system, the amount of $\mathrm{H}_{2} \mathrm{O}_{2}$ dramatically increased (Figure 5, red $\mathbf{m}$ ). The TON with respect to 1 and FMN reached 201 at $4 \mathrm{~h}$. When $1(1.0 \mu \mathrm{M})$ and FMN $(50 \mu \mathrm{M})$ were used, the TON based on 1 reached 847 at $4 \mathrm{~h}$. The product yield of $\mathrm{H}_{2} \mathrm{O}_{2}$ based on the total amount of $\mathrm{H}_{2}$ and $\mathrm{O}_{2}$ supplied in the catalytic reaction system was $19.2 \%$ at $10 \mathrm{~min}$ (Figure S7 in the Supporting Information). This value is more than three times larger than that obtained in the nanocolloidal $\mathrm{Pd}-\mathrm{Au}$ system under normal pressure of a $\mathrm{H}_{2} / \mathrm{O}_{2}$ gas mixture $(6.1 \%)$. ${ }^{[1 \mathrm{~d}]}$ The rate of catalytic formation of $\mathrm{H}_{2} \mathrm{O}_{2}$ is accelerated with $\left[\mathrm{Sc}^{3+}\right.$ ] (Figure 5) and reached a turnover frequency (TOF) of $50 \mathrm{~h}^{-1}$, however, the rate remained unchanged on increasing the concentration of $\mathrm{Sc}^{3+}$ over $50 \mathrm{~mm}$. The limited TOF might be caused by the loss of $\mathrm{H}_{2} \mathrm{O}_{2}$ through the catalytic reduction of $\mathrm{H}_{2} \mathrm{O}_{2}$ by $\mathrm{H}_{2}$ with 1 to produce $\mathrm{H}_{2} \mathrm{O}$ (Scheme 2). This was

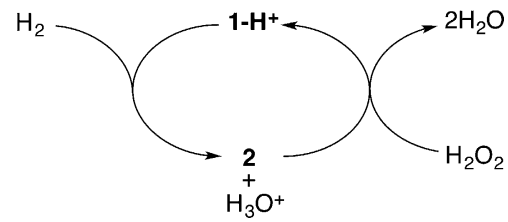

Scheme 2.

independently confirmed by the reduction of $\mathrm{H}_{2} \mathrm{O}_{2}$ by $\mathrm{H}_{2}$ when using $\mathbf{1}$ in water in the absence and presence of $\mathrm{Sc}\left(\mathrm{NO}_{3}\right)_{3}$ (Figure $\mathrm{S} 8$ in the Supporting Information).

The reduction of $\mathrm{H}_{2} \mathrm{O}_{2}$ to $\mathrm{H}_{2} \mathrm{O}$ by $\mathrm{H}_{2}$ was catalyzed by 1 (Figure S8 in the Supporting Information, black $\bullet$ ). However, this reaction was effectively retarded by the presence of $\mathrm{Sc}^{3+}$ (Figure S8 in the Supporting Information, blue $\bullet$ and red $\Delta)$, thus indicating that the further hydrogenation of $\mathrm{H}_{2} \mathrm{O}_{2}$ as shown in Scheme 2 could be inhibited by the presence of strong acid; a result consistent with the fact that $\mathrm{H}_{2} \mathrm{O}_{2}$ is known to be stabilized under acidic conditions. ${ }^{[20]}$ In the same manner as in heterogeneous catalytic systems, the decomposition of $\mathrm{H}_{2} \mathrm{O}_{2}$ directly synthesized from $\mathrm{H}_{2}$ and $\mathrm{O}_{2}$ in reactions catalyzed by carbon- or $\mathrm{TiO}_{2}$ - supported $\mathrm{Au}, \mathrm{Pd}$, or an $\mathrm{Au}-\mathrm{Pd}$ alloy was strongly retarded by the pretreatment of the catalyst with acid. ${ }^{[5 \mathrm{a}, \mathrm{c}]}$

The rate-determining step of the catalytic scheme shown in Scheme 1 was investigated by examining the dependence of the overall rate of catalytic $\mathrm{H}_{2} \mathrm{O}_{2}$ production on the concentration of $\mathbf{1}$. The rate of formation of $\mathrm{H}_{2} \mathrm{O}_{2}$ from $\mathrm{H}_{2}$ and $\mathrm{O}_{2}$ when using 1 in the presence of $\mathrm{Sc}\left(\mathrm{NO}_{3}\right)_{3}$ increased with increasing concentrations of $\mathbf{1}$ (Figure $\mathrm{S} 9$ in the Supporting Information), thus indicating that the rate-determining step is the reduction of FMN to $\mathrm{FMNH}_{2}$ by 2 to regenerate $\mathbf{1}^{[21]}$ The characteristic UV/Vis absorption bands of FMN in the presence of 1 under $\mathrm{N}_{2}$ (Figure $\mathrm{S} 10 \mathrm{a}$ in the Supporting Information) remained unchanged under both $\mathrm{H}_{2}$ and $\mathrm{O}_{2}$ throughout the catalytic reaction (Figure S10b), thus indicating that FMN reduction by $\mathbf{2}$ is the rate-determining step of the overall catalytic reaction at $\mathrm{pH} 6.0$. Under these con- 
ditions, selective two-electron reduction of $\mathrm{O}_{2}$ to $\mathrm{H}_{2} \mathrm{O}_{2}$ occurs without the further reduction of $\mathrm{H}_{2} \mathrm{O}_{2}$ to $\mathrm{H}_{2} \mathrm{O}$.

In conclusion, the water-soluble iridium(III) complex 1 can efficiently catalyze the direct synthesis of $\mathrm{H}_{2} \mathrm{O}_{2}$ from $\mathrm{H}_{2}$ and $\mathrm{O}_{2}$ when using a water-soluble flavin (FMN) under normal pressure in aqueous solution at $298 \mathrm{~K}$. The catalytic cycle consists of the reduction of $\mathbf{1}$ by $\mathrm{H}_{2}$ to form the $\mathrm{Ir}^{\mathrm{III}}-\mathrm{H}$ complex 2 , followed by the reduction by 2 of FMN to $\mathrm{FMNH}_{2}$, which then reacts with $\mathrm{O}_{2}$ to produce $\mathrm{H}_{2} \mathrm{O}_{2}$, accompanied by the regeneration of FMN and 1 . The addition of $\mathrm{Sc}\left(\mathrm{NO}_{3}\right)_{3}$ led to a high TON (847) and a reasonably high yield of $\mathrm{H}_{2} \mathrm{O}_{2}$ $(19.2 \%)$. This is because $\mathrm{Sc}\left(\mathrm{NO}_{3}\right)_{3}$ can inhibit the catalytic reduction of $\mathrm{H}_{2} \mathrm{O}_{2}$ by $\mathrm{H}_{2}$ when using 1 .

\section{Experimental Section}

All experiments were performed under an $\mathrm{Ar}$ or $\mathrm{N}_{2}$ atmosphere by using standard Schlenk techniques unless otherwise noted. The limiting concentration of $\mathrm{O}_{2}$ in aqueous solution was prepared by using a mixed gas flow of $\mathrm{O}_{2}$ and $\mathrm{N}_{2}$ under normal pressure $(1.0 \times$ $10^{-1} \mathrm{MPa}$ ). The mixed gas was controlled by using a gas mixer (Kofloc GB-3C, KOJIMA Instrument Inc.), which can mix two or more gases at a defined partial pressure and mass flow rate. A defined concentration of $\mathrm{H}_{2}$ in an aqueous solution was prepared by a mixed gas flow of $\mathrm{H}_{2}$ and $\mathrm{N}_{2}$ (or $\mathrm{O}_{2}$ ) controlled by using a gas flow meter (KOJIMA Instrument Inc.) appropriate for each gas under normal pressure $\left(1.0 \times 10^{-1} \mathrm{MPa}\right)$. UV/Vis absorption spectra were recorded on a Hewlett-Packard 8453 diode array spectrophotometer with a quartz cuvette (light-path length $=1 \mathrm{~cm}$ ) at $298 \mathrm{~K}$. Kinetic measurements for reactions with short half-lives (under $10 \mathrm{~s}$ ) were performed on a UNISOKU RSP-601 stopped-flow spectrometer equipped with a MOS-type highly sensitive photodiode array at $298 \mathrm{~K}$. Because the $\mathrm{O}_{2} / \mathrm{H}_{2}$ ratio is within the explosive range, dry catalyst should not be added to the $\mathrm{O}_{2} / \mathrm{H}_{2}$ gas mixture. Moreover, precautions should be taken to contain the system in the event of an explosion.

Details concerning chemicals, determination of the reaction yield, detection of $\mathrm{H}_{2} \mathrm{O}_{2}$, and $\mathrm{pH}$ adjustment are described in the Supporting Information.

Received: August 19, 2013

Revised: September 9, 2013

Published online: October 25, 2013

Keywords: homogeneous catalysis - hydrogen .

hydrogen peroxide $\cdot$ iridium $\cdot$ oxygen

[1] a) R. Hage, A. Lienke, Angew. Chem. 2006, 118, 212-229; Angew. Chem. Int. Ed. 2006, 45, 206-222; b) W. H. Hart, S. J. Hsieh, Am. Inst. Chem. Eng. Symp. 1998, 319, 73-76; c) B. S. Lane, K. Burgess, Chem. Rev. 2003, 103, 2457-2474; d) G. De Faveri, G. Ilyashenko, M. Watkinson, Chem. Soc. Rev. 2011, 40, $1722-1760$.

[2] a) S. Fukuzumi, Y. Yamada, K. D. Karlin, Electrochim. Acta 2012, 82, 493-511; b) Y. Yamada, S. Yoshida, T. Honda, S. Fukuzumi, Energy Environ. Sci. 2011, 4, 2822-2825; c) R. S. Disselkamp, Int. J. Hydrogen Energy 2010, 35, 1049-1053.

[3] J. M. Campos-Martin, G. Blanco-Brieva, J. L. G. Fierro, Angew. Chem. 2006, 118, 7116-7139; Angew. Chem. Int. Ed. 2006, 45, $6962-6984$

[4] C. Samanta, Appl. Catal. A 2008, 350, 133-149.

[5] a) J. K. Edwards, B. Solsona, E. N. Ntainjua, A. F. Carley, A. A. Herzing, C. J. Kiely, G. J. Hutchings, Science 2009, 323, $1037-$
1041; b) J. K. Edwards, G. J. Hutchings, Angew. Chem. 2008, 120, 9332-9338; Angew. Chem. Int. Ed. 2008, 47, $9192-9198 ;$ c) J. K. Edwards, E. N. Ntainjua, A. F. Carley, A. A. Herzing, C. J. Kiely, G. J. Hutchings, Angew. Chem. 2009, 121, 8664-8667; Angew. Chem. Int. Ed. 2009, 48, 8512-8515; d) E. N. Ntainjua, M. Piccinini, J. C. Pritchard, J. K. Edwards, A. F. Carley, J. A. Moulijn, G. J. Hutchings, ChemSusChem 2009, 2, 575-580; e) S. J. Freakley, M. Piccinini, J. K. Edwards, E. N. Ntainjua, J. A. Moulijn, G. J. Hutchings, ACS Catal. 2013, 3, 487-501; f) E. N. Ntainjua, S. J. Freakley, G. Hutchings, Top. Catal. 2012, 55, $718-$ $722 ;$ g) E. N. Ntainjua, M. Piccinini, S. J. Freakley, J. C. Pritchard, J. K. Edwards, A. F. Carley, G. J. Hutchings, Green Chem. 2012, $14,170-181$.

[6] a) M. Sun, J. Zhang, Q. Zhang, Y. Wang, H. Wan, Chem. Commun. 2009, 5174-5176; b) S. Park, S. H. Lee, S. H. Song, D. R. Park, S.-H. Baeck, T. J. Kim, Y.-M. Chung, S.-H. Oh, I. K. Song, Catal. Commun. 2009, 10, 391-394.

[7] Q. S. Liu, J. C. Bauer, R. E. Schaak, J. H. Lunsford, Angew. Chem. 2008, 120, 6317-6320; Angew. Chem. Int. Ed. 2008, 47, $6221-6224$.

[8] a) G. B. Brieva, J. M. Campos-Martin, M. P. de Frutos, J. L. G. Fierro, Catal. Today 2010, 158, 97-102; b) G. Blanco-Brieva, M. P. D. Escrig, J. M. Campos-Martin, J. L. G. Fierro, Green Chem. 2010, 12, 1163-1166.

[9] J. Kim, Y.-M. Chung, S.-M. Kang, C.-H. Choi, B.-Y. Kim, Y.-T. Kwon, T. J. Kim, S.-H. Oh, C.-S. Lee, ACS Catal. 2012, 2, $1042-$ 1048.

[10] T. García, R. Murillo, S. Agouram, A. Dejoz, M. Lázaro, L. Torrente-Murciano, B. Solsona, Chem. Commun. 2012, 48, $5316-5318$.

[11] a) K. Mori, K. Furubayashi, S. Okada, H. Yamashita, $R S C A d v$. 2012, 2, 1047-1054; b) T. Deguchi, H. Yamano, M. Iwamoto, $J$. Catal. 2012, 287, 55-61; c) T. Ishihara, R. Nakashima, Y. Nomura, Catal. Sci. Technol. 2012, 2, $961-968$; d) Y. Nomura, T. Ishihara, Y. Hata, K. Kitawaki, K. Kaneko, H. Matsumoto, ChemSusChem 2008, 1, 619-621; e) Q. Chen, E. J. Beckman, Green Chem. 2007, 9, 802-808.

[12] a) J. Xu, L. Ouyang, G.-J. Da, Q.-Q. Song, X.-J. Yang, Y.-F. Han, J. Catal. 2012, 285, 74-82; b) Y.-F. Han, Z. Zhong, K. Ramesh, F. Chen, L. Chen, T. White, Q. Tay, S. N. Yaakub, Z. Wang, J. Phys. Chem. C 2007, 111, 8410-8413.

[13] In homogeneous catalytic systems for the reaction of $\mathrm{H}_{2}$ with $\mathrm{O}_{2}$, no formation of $\mathrm{H}_{2} \mathrm{O}_{2}$ has been confirmed, see: a) Z. M. Heiden, T. B. Rauchfuss, J. Am. Chem. Soc. 2007, 129, 14303-14310; b) L. Vaska, M. E. Tadros, J. Am. Chem. Soc. 1971, 93, 70997101, whereas, a small amount of $\mathrm{H}_{2} \mathrm{O}_{2}$ was qualitatively detected, see: c) A. S. Berenblyum, A. G. Knizhnik, S. L. Mund, I. I. Moiseev, J. Organomet. Chem. 1982, 234, 219-235.

[14] a) Y. Maenaka, T. Suenobu, S. Fukuzumi, J. Am. Chem. Soc. 2012, 134, 367-374; b) Y. Maenaka, T. Suenobu, S. Fukuzumi, Energy Environ. Sci. 2012, 5, 7360-7367; c) Y. Maenaka, T. Suenobu, S. Fukuzumi, J. Am. Chem. Soc. 2012, 134, 9417-9427.

[15] A water-soluble $\operatorname{Ir}^{\mathrm{III}}$ porphyrin was reported to react with $\mathrm{H}_{2}$ to produce the corresponding iridium(III) hydride complex, see: a) S. Bhagan, B. B. Wayland, Inorg. Chem. 2011, 50, $11011-$ 11020 ; b) S. Bhagan, G. H. Imler, B. B. Wayland, Inorg. Chem. 2013, 52, 4611-4617.

[16] a) A. S. Eisenberg, J. P. M. Schelvis, J. Phys. Chem. A 2008, 112, 6179-6189; b) Z. Shi, J. M. Zachara, L. Shi, Z. Wang, D. A. Moore, D. W. Kennedy, J. K. Fredrickson, Environ. Sci. Technol. 2012, 46, 11644-11652.

[17] a) S. Fukuzumi, S. Kuroda, T. Tanaka, J. Am. Chem. Soc. 1985, 107, 3020-3027; b) S. Fukuzumi, K. Tanii, T. Tanaka, Chem. Commun. 1989, 816-818.

[18] J. Sucharitakul, M. Prongjit, D. Haltrich, P. Chaiyen, Biochemistry 2008, 47, 8485-8490. 
[19] C. Matsubara, N. Kawamoto, K. Takamura, Analyst 1992, 117, $1781-1784$.

[20] Hydrogenation was reported to be a major pathway for $\mathrm{H}_{2} \mathrm{O}_{2}$ decomposition on $\mathrm{Pd}$ or $\mathrm{Pd}-\mathrm{Au}$ alloy supported on SBA-15, see: N. Gemo, P. Biasi, P. Canu, F. Menegazzo, F. Pinna, A Samikannu, K. Kordás, T. O. Salmi, J.-P. Mikkola, Top. Catal. 2013, 56, 540-549.

[21] The maximum rate of this reaction step $\left(r_{\mathrm{B}, \max }\right)$ in Scheme 1 under catalytic reaction conditions in the absence of $\mathrm{Sc}\left(\mathrm{NO}_{3}\right)_{3}$ was determined to be $r_{\mathrm{B}, \max }=k_{\mathrm{B}}[\mathrm{FMN}]_{\max }[2]_{\max }=1.5 \times$
$10^{5}\left(\mathrm{M}^{-1} \mathrm{~s}^{-1}\right) \times 5.0 \times 10^{-6}(\mathrm{M}) \times 5.0 \times 10^{-6}(\mathrm{M})=3.8 \times 10^{-6} \mathrm{M} \mathrm{s}^{-1}$. This value is significantly smaller than that for the next catalytic step $\left(r_{\mathrm{C}, \max }\right)$, the reduction of $\mathrm{O}_{2}$ by $\mathrm{FMNH}_{2}$, which was determined to be $r_{\mathrm{C}, \max }=k_{\mathrm{C}}\left[\mathrm{FMNH}_{2}\right]_{\max }\left[\mathrm{O}_{2}\right]=2.8 \times$ $10^{4}\left(\mathrm{M}^{-1} \mathrm{~s}^{-1}\right) \times 5.0 \times 10^{-6}(\mathrm{M}) \times 1.4 \times 10^{-3}(\mathrm{M})=2.0 \times 10^{-4} \mathrm{M} \mathrm{s}^{-1}$. The reaction rate of the first catalytic step $\left(r_{\mathrm{A}}\right)$, the reaction of 1 with $\mathrm{H}_{2}$, can be evaluated based on the data in Figure $\mathrm{S} 1$ in the Supporting Information, and was determined to be $r_{\mathrm{A}}>6.0 \times$ $10^{-6} \mathrm{M} \mathrm{s}^{-1}>r_{\mathrm{B}, \max }$ 